\title{
PENGARUH VARIASI DAN KEMASAN PRODUK TERHADAP KEPUTUSAN PEMBELIAN TEH KOTAK ULTRAJAYA \\ (Survei pada Mahasiswa FPIPS Universitas Pendidikan Indonesia)
}

\author{
B. Lena Nuryanti \\ Anisa Yunia Rahman
}

\begin{abstract}
Abstrak
Persaingan terjadi pada berbagai sektor baik industri jasa dan non jasa. Salah satunya adalah industri minuman, persaingan dalam bisnis yang satu ini cukup tinggi, industri ini cukup menarik untuk dibahas karena di sebagian masyarakat minuman merupakan kebutuhan sehari-hari, terutama teh dalam kemasan sebagai pelengkap makanan yang dikonsumsi oleh masyarakat, sehingga hal ini menyebabkan persaingan diantara berbagai perusahaan dalam menciptakan produk minuman untuk memenuhi kebutuhan konsumen. Tidak terkecuali Teh Kotak Ultrajaya sebagai pelopor minuman teh dalam kemasan berusaha untuk melakukan strategi variasi produk dan kemasan agar konsumen tidak lari kepada merek lain. Hal ini menunjukkan bahwa persaingan di antara merek-merek minuman teh dalam kemasan semakin ketat. Tujuan penelitian ini adalah untuk mengetahui deskripsi variasi produk yang meliputi ukuran, harga, dan rasa; deskripsi kemasan yang terdiri atas bentuk, bahan, warna, gambar, dan label; deskripsi keputusan pembelian yang meliputi pilihan jenis produk, pilihan bentuk produk, pilihan merek, pilihan saluran penjual, dan waktu pembelian; serta untuk mengetahui seberapa besar pengaruh variasi produk dan kemasan terhadap keputusan pembelian Teh Kotak Ultrajaya pada mahasiswa FPIPS UPI.

Metode penelitian yang digunakan adalah metode deskriptif dan explanatory survey. Dengan jangka waktu pengembangan penelitian bersifat cross sectional method. Populasi penelitian berjumlah 210 orang yang merupakan mahasiswa FPIPS UPI yang terdaftar Aktif. Berdasarkan teknik penarikan sampel secara simple random sampling dan menggunakan rumus Slovin diperoleh sampel sebesar 68 sampel, namun untuk meningkatkan keakuratan maka jumlah sampel yang diteliti ditambah sehingga berjumlah 70 sampel. Data yang digunakan adalah data primer dan sekunder dengan teknik pengumpulan data melalui wawancara, observasi, penyebaran kuesioner dan studi literatur. Pengujian hipotesis dilakukan dengan menggunakan path analysis dengan bantuan software komputer SPSS 11.5 for Windows.

Hasil penelitian menunjukkan bahwa variasi produk minuman teh dalam kemasan Teh Kotak Ultrajaya terdiri dari ukuran, harga, dan rasa. Dimana indikator harga memperoleh skor tertinggi dan indikator rasa memperoleh skor terendah. Kemasan Teh Kotak Ultrajaya terdiri dari bentuk, bahan, warna, gambar, dan label. Dimana skor tertinggi diperoleh indikator bahan kemasan sedangkan skor terkecil diperoleh indikator warna. Keputusan pembelian yang terdiri dari jenis produk, bentuk produk, pilihan merek, pilihan saluran penjual dan waktu pembelian, dapat diketahui bahwa indikator yang memperoleh skor tertinggi adalah kemudahan mendapatkan produk melalui saluran penjual sedangkan indikator ketertarikan pada bentuk produk dan jenis produk varian rasa memperoleh skor terkecil. Terdapat pengaruh yang positif dan signifikan dari variasi dan kemasan produk terhadap keputusan pembelian Teh Kota Ultrajaya pada Mahasiswa FPIPS UPI baik secara parsial maupun simultan dengan pengaruh sebesar 67,93\% atau bisa dikategorikan ke dalam korelasi kuat, sedangkan sebesar 32,07\% dipengaruhi oleh faktor lain yang tidak diteliti.
\end{abstract}

\section{Kata Kunci: Variasi Produk, Kemasan Produk, dan Keputusan Pembelian}

\section{PENDAHULUAN}

Pertumbuhan ekonomi dalam era globalisasi menuntut setiap perusahaan baik yang bergerak dalam bidang industri maupun jasa mampu bersaing dengan perusahaan lainnya. Persaingan terjadi pada berbagai sektor baik industri jasa dan non jasa.

Salah satunya adalah industri minuman, persaingan dalam bisnis yang satu ini cukup tinggi, industri ini cukup menarik untuk dibahas karena di sebagian masyarakat minuman merupakan 
kebutuhan sehari-hari, terutama teh dalam kemasan sebagai pelengkap makanan yang dikonsumi oleh masyarakat, sehingga hal ini menyebabkan persaingan diantara berbagai perusahaan dalam menciptakan produk minuman untuk memenuhi kebutuhan konsumen.

Tingginya tingkat persaingan industri minuman khususnya minuman teh dalam kemasan yang semakin beragam akan mempengaruhi tingkat keputusan pembelian konsumen. Macam-macam rasa dan merek minuman dalam kemasan bermunculan dan terus bersaing sesuai dengan pasarnya masing-masing dan konsumen akan dihadapkan pada berbagai jenis minuman dengan variasi yang berbeda.

Adapun merek-merek minuman teh dalam kemasan yang saat ini sedang berkembang yaitu Teh Sosro, Frestea, Fruit tea, Tekita, Teh Kotak Ultrajaya. Dengan berbagai macam rasa dan kemasan yang berbeda serta keunggulan masingmasing produk ditawarkan kepada konsumen dalam rangka memenangkan persaingan. Tidak terkecuali Teh Kotak Ultrajaya sebagai pelopor minuman teh dalam kemasan berusaha untuk melakukan inovasi produk agar konsumen tidak lari kepada merek lain.

Hal ini menunjukkan bahwa persaingan di antara merek-merek minuman teh dalam kemasan semakin ketat. Menghadapi kenyataan demikian, perusahaan dituntut untuk dapat mengembangkan kebijakan pemasaran yang aktif serta senantiasa mengikuti perkembangan ilmu pengetahuan, teknologi dan ekonomi.

Berikut ini disajikan data mengenai pangsa pasar teh siap minum dalam kemasan tahun 20062007.

Tabel 1

Pangsa Pasar Teh Siap Minum dalam Kemasan Tahun 2006-2007

\begin{tabular}{|c|c|c|c|}
\hline \multirow{2}{*}{ No. } & \multirow{2}{*}{ Merek } & \multicolumn{2}{|c|}{ Pangsa Pasar } \\
\cline { 3 - 4 } & & $\mathbf{2 0 0 6}$ & $\mathbf{2 0 0 7}$ \\
\hline 1. & Teh Sosro & $81,5 \%$ & $67,1 \%$ \\
\hline 2. & Frestea & $5,3 \%$ & $6,8 \%$ \\
\hline 3. & Fruit tea & $5,3 \%$ & $8,5 \%$ \\
\hline 4. & Tekita & $3,3 \%$ & $2,3 \%$ \\
\hline 5. & $\begin{array}{c}\text { Teh Kotak } \\
\text { Ultrajaya }\end{array}$ & $\mathbf{1 , 5 \%}$ & $\mathbf{1 , 4 \%}$ \\
\hline
\end{tabular}

Sumber : Majalah Swa No. 20/XX/1/21 September- 4 Oktober 2006 dan 16/XX III/26 Juli- 8 Agustus 2007

Teh Kotak merupakan pelopor utama untuk minuman teh dalam kemasan. Hal tersebut menjelaskan adanya permasalahan pada keputusan pembelian Teh Kotak Ultrajaya.
Tabel 1 menunjukkan bahwa pangsa pasar Teh Sosro tahun 2006 yaitu sebesar 81,5\%, pangsa pasar untuk Frestea sebesar 5,3\%, Fruit tea sebesar 5,3\%, Tekita sebesar 3,3\%, dan Teh Kotak Ultrajaya menduduki posisi terakhir dalam pasar teh yaitu hanya sebesar $1,5 \%$, sedangkan untuk tahun 2007 pangsa pasar Teh Sosro yaitu sebesar $67,1 \%$, pangsa pasar Frestea sebesar $6,8 \%$, pangsa pasar Fruit tea sebesar 8,5\%, Tekita sebesar 2,3\%, dan Teh Kotak Ultrajaya sebesar $1,4 \%$. Jadi dalam hal ini Teh Sosro masih menguasai pasar teh, lain halnya dengan Teh Kotak Ultrajaya yang menempati posisi terakhir untuk pangsa pasar teh siap minum dalam kemasan tahun 2006-2007 padahal Teh Kotak merupakan pelopor utama untuk minuman teh dalam kemasan. Hal tersebut menjelaskan adanya permasalahan pada keputusan pembelian Teh Kotak Ultrajaya. Peneliti mencoba mencari penyebab dari permasalahan tersebut dengan cara melakukan pra penelitian kepada 100 responden yaitu mahasiswa FPIPS UPI angkatan 2003.

Untuk lebih mengetahui dengan jelas mengenai persaingan teh siap minum dalam kemasan, berikut ini akan disajikan data hasil pra penelitian. Dari hasil survei pra penelitian didapat hasil yang menunjukkan kesan kurang baik terhadap Teh Kotak Ultrajaya. Hal tersebut dapat dilihat dari hasil tanggapan responden mengenai pilihan utama teh siap minum dalam kemasan berikut ini.

Tabel 2

Pilihan Utama Teh Siap Minum dalam Kemasan

\begin{tabular}{|c|c|c|}
\hline No. & Merek & Persentase \\
\hline 1. & Fruit tea & 45 \\
\hline 2. & Teh Sosro & 29 \\
\hline 3. & Frestea & 17 \\
\hline 4. & Teh Kotak Ultrajaya & $\mathbf{9}$ \\
\hline
\end{tabular}

Sumber : Hasil Pra Penelitian 2007

Tabel 2 menunjukkan bahwa hanya sebesar 9\% responden memilih Teh Kotak Ultrajaya sebagai pilihan teh siap minum dalam kemasan. Merek yang menjadi pilihan utama responden yaitu Fruit Tea sebesar $45 \%$. Pilihan kedua responden yaitu Teh Sosro sebesar 29\%, sedangkan untuk pilihan ketiga responden yaitu Frestea sebesar 17\%. Dari data diatas dapat disimpulkan bahwa Teh Kotak Ultrajaya bukan merupakan pilihan utama teh dalam kemasan yang dikonsumsi oleh konsumen. Dalam hal ini Teh Kotak Ultrajaya 
masih belum mampu menguasai pasar teh siap minum dalam kemasan.

Berikut ini disajikan data mengenai alasan responden dalam memilih teh siap minum dalam kemasan.

Tabel 3

Alasan Memilih Teh Siap Minum dalam Kemasan

\begin{tabular}{|c|c|c|}
\hline No. & Alasan & Frekuensi \\
\hline 1. & Harga & 9 \\
\hline 2. & Rasa & 76 \\
\hline 3. & Kemasan & 10 \\
\hline 4. & Praktis & 5 \\
\hline
\end{tabular}

Sumber : Hasil Pra Penelitian 2007

Tabel 3 menunjukkan bahwa 76 responden memilih teh siap minum dalam kemasan karena rasa, 9 responden memilih karena harga, 10 responden memilih karena kemasan, dan 5 responden memilih karena praktis. Jadi dalam suatu produk minuman teh yang paling diutamakan oleh konsumen adalah rasa. Oleh karena itu perusahaan harus teliti dalam usaha memenuhi kebutuhan dan keinginan konsumen. Salah satu caranya yaitu dengan mengutamakan rasa, karena rasa merupakan hal yang paling utama dalam suatu produk dengan rasa suatu produk akan mampu memberikan kepuasan terhadap konsumen dan hal itu akan mempengaruhi keputusan pembelian konsumen terhadap suatu produk.

Strategi dalam memperbaiki tingkat keputusan pembelian Teh Kotak Ultrajaya dapat dilakukan dengan melakukan berbagai inovasi terhadap produknya, berdasarkan hasil pra penelitian yang penulis lakukan pada 100 responden mahasiswa FPIPS UPI angkatan 2003, memberikan saran mengenai strategi yang cocok untuk meningkatkan keputusan pembelian Teh Kotak Ultrajaya. Berikut ini disajikan tanggapan responden mengenai strategi yang cocok untuk Teh Kotak Ultrajaya.

\section{Tabel 4}

Tanggapan Responden Mengenai Strategi yang Cocok untuk Teh Kotak Ultrajaya

\begin{tabular}{|l|l|c|}
\hline No. & Strategi Teh Kotak Ultrajaya & Frekuensi \\
\hline 1. & Varian rasa & 46 \\
\hline 2. & Kualitas produk & 10 \\
\hline 3. & Rancangan produk & 3 \\
\hline 4 & Fitur & 4 \\
\hline 5. & Merek produk & 1 \\
\hline 6. & Kemasan & 31 \\
\hline 7. & Ukuran produk & 5 \\
\hline
\end{tabular}

Sumber : Hasil Pra Penelitian 2007
Tabel 4 menunjukkan bahwa sebanyak 46 responden menyatakan strategi yang cocok untuk Teh Kotak Ultrajaya adalah varian rasa, 31 responden menyatakan bahwa strategi yang cocok adalah kemasan, 10 responden menyatakan kualitas produk, 5 responden menyatakan strategi yang cocok adalah ukuran produk, 4 responden menyatakan fitur produk, 3 responden menyatakan rancangan produk dan seorang responden menyatakan strategi yang cocok adalah merek produk.. Dari data diatas dapat memberikan gambaran bagi penulis untuk menjadikan varian rasa dan kemasan menjadi strategi yang cocok dalam meningkatkan keputusan pembelian Teh Kotak Ultrajaya.

Teh Kotak Ultrajaya dalam perkembangannya melakukan berbagai strategi perbaikan produknya dengan menambahkan varian rasa buah-buahan yaitu rasa blackcurrant, orange, dan apple, selain itu juga Teh Kotak Ultrajaya melakukan strategi kemasan yaitu dengan kemasan ekstra $50 \%$ untuk jenis jasmine tea, dan ekstra $25 \%$ untuk jenis varian rasa. Hal tersebut merupakan salah satu cara untuk menarik pelanggan melalui variasi rasa dan kemasan dengan isi yang lebih banyak. Dengan strategi ini perusahaan mengharapkan dapat meningkatkan keputusan pembelian terhadap Teh Kotak Ultrajaya.

Berikut ini disajikan tanggapan responden mengenai jenis pilihan Teh Kotak Ultrajaya yang disukai.

Tabel 5

Tanggapan Responden Mengenai Jenis Pilihan Teh Kotak Ultrajaya

\begin{tabular}{|l|l|c|}
\hline NO. & \multicolumn{1}{|c|}{ PILIHAN TEH KOTAK } & FREKUENSI \\
\hline 1. & Jasmine Tea & 45 \\
\hline 2. & Varian rasa orange & 15 \\
\hline 3. & Varian rasa blackcurrant & 25 \\
\hline 4 & Varian rasa apple & 15 \\
\hline
\end{tabular}

Sumber : Hasil Pra Penelitian 2007

Tabel 5 menunjukkan sebanyak 45 responden memilih Jasmine Tea, sebesar 15 responden memilih rasa orange, 25 responden memilih blackcurrant, dan 15 responden memilih rasa apple. Dengan demikian dapat diambil kesimpulan bahwa sebagian besar responden lebih menyukai jenis jasmine tea dibandingkan dengan jenis varian rasa.

Dewasa ini kemasan telah menjadi sesuatu yang lebih berarti dan konsep kemasan telah menjadi bagian penting dalam keberadaan ekonomi. Kemasan yang digunakan oleh 


\section{StrategiC}

perusahaan juga penting untuk memperbesar jumlah konsumen dan hal tersebut juga ditujukan untuk melindungi serta mempromosikan produk yang bersangkutan.

Banyak perusahaan yang sangat memperhatikan kemasan suatu produk sebab mereka menganggap bahwa fungsi kemasan tidak hanya sebagai pembungkus, tetapi jauh lebih luas dari pada itu. Jika pihak penjual/produsen memperhatikan fungsi-fungsi tersebut maka kelancaran penjualan barang-barang dapat diharapkan. Salah satu aspek yang banyak diabaikan dalam kemasan adalah keindahan, padahal keindahan kemasan besar pengaruhnya terhadap keberhasilan penjualan, meskipun faktor biaya harus pula diperhatikan.

Strategi yang dilakukan Teh Kotak Ultrajaya dalam meningkatkan keputusan pembelian yaitu dengan kemasan ekstra berikut ini.

Tabel 6

Strategi Kemasan Teh Kotak Ultrajaya

\begin{tabular}{|l|c|}
\hline \multicolumn{1}{|c|}{ Jenis Produk } & Strategi kemasan \\
\hline Jasmine tea & $50 \%$ ekstra \\
\hline Varian rasa & $25 \%$ ekstra \\
\hline
\end{tabular}

Sumber : PT. Ultrajaya Milk Industry

Berdasarkan Tabel 6 dapat dilihat bahwa strategi kemasan yang dilakukan Teh Kotak Ultrajaya untuk jenis jasmine tea dilakukan penambahan volume/isi $50 \%$ ekstra, sedangkan untuk jenis varian rasa sebanyak $25 \%$ ekstra. Hal tersebut diharapkan mampu meningkatkan keputusan pembelian konsumen.

Berangkat dari latar belakang tersebut maka perlu diadakan penelitian yang dirumuskan dalam rumusan masalah sebagai berikut:

1. Bagaimana tanggapan responden terhadap variasi produk Teh Kotak Ultrajaya yang meliputi ukuran, harga dan rasa.

2. Bagaimana tanggapan responden terhadap kemasan Teh Kotak Ultrajaya yang meliputi bentuk, bahan, warna, gambar, dan label.

3. Bagaimana tanggapan responden terhadap keputusan pembelian Teh Kotak Ultrajaya yang meliputi pilihan jenis produk, pilihan bentuk produk, pilihan merek, pilihan saluran penjual, dan waktu pembelian.

4. Seberapa besar pengaruh variasi produk yang meliputi ukuran, harga dan rasa terhadap keputusan pembelian minuman teh siap dalam kemasan Teh Kotak Ultrajaya.
5. Seberapa besar pengaruh kemasan yang meliputi bentuk, bahan, warna, gambar, dan label terhadap keputusan pembelian minuman teh siap dalam kemasan Teh Kotak Ultrajaya.

6. Seberapa besar pengaruh variasi produk yang meliputi ukuran, harga dan rasa dan kemasan yang meliputi bentuk, bahan, warna, gambar, dan label terhadap keputusan pembelian minuman teh siap dalam kemasan Teh Kotak Ultrajaya.

\section{KERANGKA PEMIKIRAN}

Pemasaran merupakan fungsi dalam perubahan yang bertugas menentukan target pelanggan serta cara terbaik untuk memuaskan kebutuhan dan keinginan mereka secara bersaing dan menguntungkan juga sebuah proses perencanaan ide, konsepsi, harga, promosi, menciptakan peluang yang nantinya mampu memuaskan individu yang sesuai dengan tujuan perusahaan.

Philip Kotler (2005:5) mengemukakan bahwa pemasaran adalah suatu proses sosial dan melalui proses itu individu dan kelompok mendapatkan apa yang mereka butuhkan dan inginkan dengan menciptakan dan memperhatikan produk dan nilai dengan individu dan kelompok lain.

Perusahaan dapat secara langsung mengendalikan variabel-variabel dengan menggunakan konsep bauran pemasaran yang terdiri dari yaitu: produk, harga, promosi, dan tempat. Keempat komponen tersebut merupakan inti dari kegiatan pemasaran pada setiap perusahaan. Menurut Kotler dan Amstrong (2006:48), yang dimaksud dengan marketing mix yaitu: The set of controllable tactical marketing tools-product, price, place, and promotion-that the firm blends to produce the response it wants in the target market.

Untuk memenangkan persaingan, setiap perusahaan harus berusaha untuk memenuhi kebutuhan konsumen secara lebih baik, yaitu dengan menggunakan suatu strategi pemasaran yang merupakan gambaran mengenai apa yang harus dilakukan oleh suatu perusahaan di suatu pasar.

Dalam menjalankan bisnisnya para pengusaha akan berusaha untuk memenangkan persaingan. Untuk itu syarat yang harus dipenuhi adalah berusaha memahami para konsumennya. Fandy Tjiptono (2002:19) mengungkapkan bahwa setiap perusahaan harus mampu memahami perilaku 
konsumen dari pasar sasarannya, karena kelangsungan hidup perusahaan tersebut sebagai organisasi yang berusaha memenuhi kebutuhan dan keinginan para konsumen sangat bergantung pada perilaku konsumennya. Melalui pemahaman perilaku konsumen pihak manajemen perusahaan dapat menyusun strategi program yang tepat dalam rangka memanfaatkan peluang yang ada dan mengungguli pesaingnya.

Agar dapat mempengaruhi konsumen dalam mengambil keputusan pembelian diperlukan suatu upaya dari perusahaan agar produknya dapat sampai ke tangan konsumen, paling tidak perusahaan tersebut berusaha untuk mengubah perilaku konsumen dan rasa tertarik , bahkan dari rasa tertarik tersebut meningkat sampai adanya keinginan untuk memiliki produk sehingga konsumen tersebut akan mengambil keputusan pembelian terhadap produk yang ditawarkan oleh perusahaan.

Salah satu upaya yang dapat dilakukan oleh perusahaan adalah menggunakan strategi bauran pemasaran yang terdiri dari $4 \mathrm{P}$. Sukses tidaknya strategi bauran pemasaran tersebut tergantung kepada respon dari konsumen terhadap produk yang ditawarkan oleh perusahaan.

Pada umumnya keputusan pembelian yang diambil konsumen terhadap suatu produk terjadi apabila timbul kebutuhan dalam dirinya. Hal ini dapat dirubah oleh perusahaan dengan menggunakan salah satu unsur bauran pemasaran yaitu melalui produk yang ditawarkan oleh perusahaan. Salah satu unsur dari bauran produk yaitu variasi produk dan kemasan, selain dapat dipergunakan untuk mempengaruhi konsumen dalam proses pengambilan keputusannya juga dapat digunakan sebagai alat bersaing.

Teh Kotak Ultrajaya sebagai merek minuman pertama di pasaran minuman teh dalam kemasan di Indonesia. Kini melengkapi pilihan produknya dengan meluncurkan minuman teh rasa buah sejak September 2005, yang terdiri dari rasa blackcurrant, orange, dan apple. Sekarang konsumen dapat menikmati kesegaran yang lengkap dari daun teh segar dan konsentrat buah asli yang ditambahkan ke dalam minuman teh tersebut. Produk baru ini tersedia dalam kemasan kotak $200 \mathrm{ml}$, namun selama masa peluncuran awal ini PT. Ultrajaya sebagai produsen Teh Kotak memberikan tambahan volume ekstra $50 \mathrm{ml}$ sehingga menjadi $250 \mathrm{ml}$ tetapi dengan harga kemasan $200 \mathrm{ml}$. Tambahan volume ekstra ini diharapkan akan memberikan kesegaran yang lama dan terasa lepas di saat minum Teh Kotak baru ini. Tambahan volume ekstra ini sama seperti dengan produk Teh Kotak untuk jenis jasmine tea. Berdasarkan strategi yang telah dilakukan oleh Teh Kotak Ultrajaya tersebut penulis mengambil variabel independen variasi produk dan kemasan serta variabel dependen yang diambil adalah keputusan pembelian.

\section{METODE PENELITIAN}

Pengaruh variasi produk dan kemasan terhadap keputusan pembelian pada produk minuman teh dalam kemasan yaitu Teh Kotak Ultrajaya. Adapun yang menjadi objek penelitian sebagai variabel bebas (Independent Variabel) atau variabel $X$ adalah variasi produk $\left(X_{1}\right)$ yang memiliki beberapa dimensi diantaranya ukuran, harga, dan rasa. Dan kemasan $\left(X_{2}\right)$ yang memiliki beberapa dimensi diantaranya bentuk, bahan, warna, gambar, dan label. Sedangkan objek yang merupakan variabel terikat (Dependent Variabel) atau variabel $Y$ adalah keputusan pembelian yang meliputi jenis produk, bentuk produk, pilihan merek, pilihan saluran penjual, dan waktu pembelian. Responden yang menjadi objek pada penelitian ini adalah mahasiswa yang mengkonsumsi minuman Teh Kotak Ultrajaya di FPIPS Universitas Pendidikan Indonesia.

Berdasarkan variabel yang diteliti maka jenis penelitian dalam peneitian ini adalah penelitian deskriptif dan verifikatif. Metode penelitian yang digunakan adalah deskriptive dan explanatory survey. Jangka waktu penelitian kurang dari satu tahun, yaitu dimulai dari Juli 2007 sampai dengan Desember 2007, maka metode pengembangannya bersifat cross sectional methode. Menurut Husein Umar (2001:45) cross sectional methode merupakan metode penelitian dengan cara mempelajari objek dalam kurun waktu tertentu (tidak berkesinambungan dalam jangka waktu panjang).

Untuk mengukur data pada masing-masing variabel terlebih dahulu harus dilakukan operasionalisasi variabel penelitian yang merupakan penjabaran konsep dari ketiga variabel baik variabel bebas $(X)$ maupun variabel terikat (Y). Variabel yang dikaji dalam penelitian ini adalah variasi produk (X1) yang terdiri dari sub variabel ukuran $(\mathrm{X} 1.1)$, harga $(\mathrm{X} 1.2)$, rasa $(\mathrm{X} 1.3)$, dan 
variabel $\mathrm{X} 2$ adalah kemasan yang terdiri dari sub variabel bentuk (X2.1), bahan (X2.2), warna (X2.3), Gambar (X2.4), dan label (X2.5) Sedangkan untuk variabel $Y$ adalah keputusan pembelian Berikut ini adalah operasionalisasi variabel secara lebih lengkap.

Tabel 7

Operasionalisasi Variabel

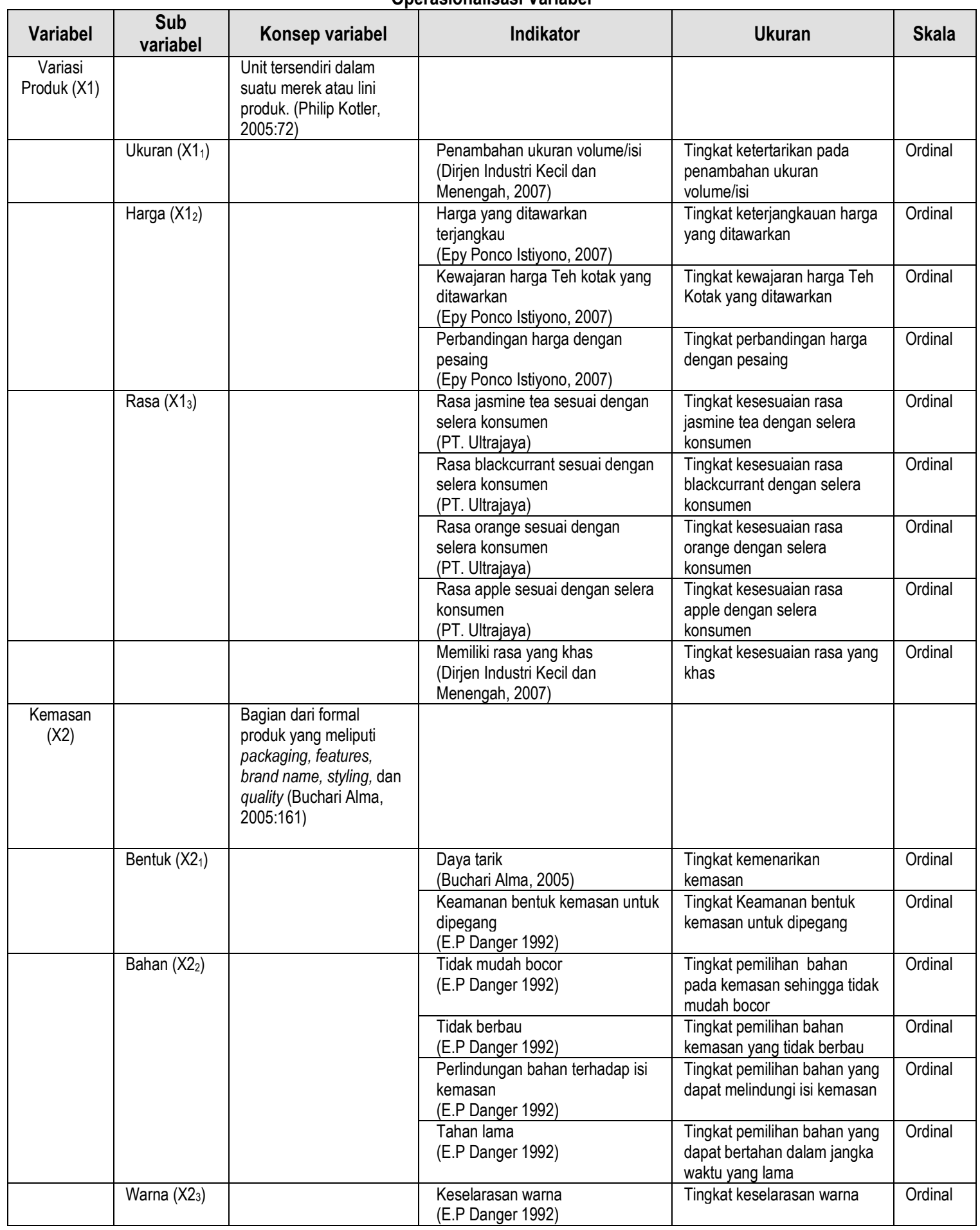




\section{StrategiC}

\begin{tabular}{|c|c|c|c|c|c|}
\hline Variabel & $\begin{array}{c}\text { Sub } \\
\text { variabel }\end{array}$ & Konsep variabel & Indikator & Ukuran & Skala \\
\hline & & & $\begin{array}{l}\text { Ketertarikan konsumen pada } \\
\text { warna kemasan } \\
\text { (E.P Danger 1992) }\end{array}$ & $\begin{array}{l}\text { Tingkat ketertarikan } \\
\text { konsumen pada warna } \\
\text { kemasan }\end{array}$ & Ordinal \\
\hline & \multirow[t]{2}{*}{$\begin{array}{l}\text { Gambar } \\
(\mathrm{X} 24)\end{array}$} & & $\begin{array}{l}\text { Gambar kemasan menarik } \\
\text { (E.P Danger 1992) }\end{array}$ & $\begin{array}{l}\text { Tingkat kemenarikan gambar } \\
\text { Tingkat kesesuain }\end{array}$ & Ordinal \\
\hline & & & $\begin{array}{l}\text { Penempatan gambar sesuai } \\
\text { (E.P Danger 1992) }\end{array}$ & penempatan gamban & Ordinal \\
\hline & \multirow[t]{4}{*}{ Label $\left(X 1_{5}\right)$} & & $\begin{array}{l}\text { Informasi kandungan gizi jelas } \\
\text { (E.P Danger 1992) }\end{array}$ & $\begin{array}{l}\text { Tingkat kejelasan informasi } \\
\text { kandungan gizi }\end{array}$ & Ordinal \\
\hline & & & $\begin{array}{l}\text { Informasi waktu kadaluarsa jelas } \\
\text { (E.P Danger 1992) }\end{array}$ & $\begin{array}{l}\text { Tingkat kejelasan informasi } \\
\text { waktu kadaluarsa }\end{array}$ & Ordinal \\
\hline & & & $\begin{array}{l}\text { Instruksi penggunaan jelas } \\
\text { (E.P Danger 1992) }\end{array}$ & $\begin{array}{l}\text { Tingkat kejelasan Instruksi } \\
\text { penggunaan }\end{array}$ & Ordinal \\
\hline & & & $\begin{array}{l}\text { Informasi berat bersih tercantum } \\
\text { dengan jelas } \\
\text { (E.P Danger 1992) }\end{array}$ & $\begin{array}{l}\text { Tingkat kejelasan informasi } \\
\text { berat bersih }\end{array}$ & Ordinal \\
\hline \multirow[t]{4}{*}{$\begin{array}{l}\text { Keputusan } \\
\text { Pembelian } \\
\text { (Y) }\end{array}$} & & $\begin{array}{l}\text { perilaku pembelian } \\
\text { akhir dari konsumen, } \\
\text { baik individual maupun } \\
\text { rumah tangga, yang } \\
\text { membeli barang-barang } \\
\text { dan jasa untuk } \\
\text { konsumsi pribadi } \\
\text { (Kotler dan Amstrong, } \\
\text { 2006:129) }\end{array}$ & & & \\
\hline & \multirow[t]{3}{*}{$\begin{array}{l}\text { Keputusan } \\
\text { tentang } \\
\text { Jenis } \\
\text { produk (Y1) }\end{array}$} & & $\begin{array}{l}\text { Keputusan pembelian } \\
\text { berdasarkan jenis produk yang } \\
\text { dikemas dalam kemasan kotak } \\
\text { (Kotler dan Amstrong, 2006) }\end{array}$ & $\begin{array}{l}\text { Tingkat keputusan pembelian } \\
\text { berdasarkan jenis produk } \\
\text { yang dikemas dalam } \\
\text { kemasan kotak }\end{array}$ & Ordinal \\
\hline & & & $\begin{array}{l}\text { Keputusan pembelian } \\
\text { berdasarkan jenis jasmine tea } \\
\text { (Kotler dan Amstrong, 2006) }\end{array}$ & $\begin{array}{l}\text { Tingkat keputusan pembelian } \\
\text { berdasarkan jenis jasmine tea }\end{array}$ & Ordinal \\
\hline & & & $\begin{array}{l}\text { Keputusan pembelian } \\
\text { berdasarkan jenis varian rasa } \\
\text { (Kotler dan Amstrong, 2006) }\end{array}$ & $\begin{array}{l}\text { Tingkat keputusan pembelian } \\
\text { berdasarkan jenis varian rasa }\end{array}$ & Ordinal \\
\hline & $\begin{array}{l}\text { Keputusan } \\
\text { tentang } \\
\text { Bentuk } \\
\text { produk (Y2) }\end{array}$ & & $\begin{array}{l}\text { Bentuk kemasan menarik } \\
\text { (Kotler dan Amstrong, 2006) }\end{array}$ & $\begin{array}{l}\text { Tingkat Kemenarikan bentuk } \\
\text { kemasan }\end{array}$ & Ordinal \\
\hline & \multirow[t]{2}{*}{$\begin{array}{l}\text { Keputusan } \\
\text { tentang } \\
\text { merek (Y3) }\end{array}$} & & $\begin{array}{l}\text { Keputusan pembelian } \\
\text { berdasarkan kualitas merek } \\
\text { (Kotler dan Amstrong, 2006) }\end{array}$ & $\begin{array}{l}\text { Tingkat keputusan pembelian } \\
\text { berdasarkan kualitas merek }\end{array}$ & Ordinal \\
\hline & & & $\begin{array}{l}\text { Keputusan pembelian } \\
\text { berdasarkan kepercayaan } \\
\text { terhadap merek } \\
\text { (Kotler dan Amstrong, 2006) } \\
\end{array}$ & $\begin{array}{l}\text { Tingkat keputusan pembelian } \\
\text { berdasarkan kepercayaan } \\
\text { terhadap merek }\end{array}$ & Ordinal \\
\hline & $\begin{array}{l}\text { Keputusan } \\
\text { tentang } \\
\text { penjual (Y4) }\end{array}$ & & $\begin{array}{l}\text { Kemudahan untuk mendapatkan } \\
\text { produk } \\
\text { (Kotler dan Amstrong, 2006) }\end{array}$ & $\begin{array}{l}\text { Tingkat Kemudahan untuk } \\
\text { mendapatkan produk }\end{array}$ & Ordinal \\
\hline & $\begin{array}{l}\text { Keputusan } \\
\text { tentang } \\
\text { Waktu } \\
\text { pembelian } \\
(\mathrm{Y} 5) \\
\end{array}$ & & $\begin{array}{l}\text { Kebutuhan } \\
\text { (Kotler dan Amstrong, 2006) }\end{array}$ & $\begin{array}{l}\text { Tingkat keputusan pembelian } \\
\text { berdasarkan kebutuhan }\end{array}$ & Ordinal \\
\hline
\end{tabular}

Sumber : Berdasarkan Hasil Pengolahan Data dan Referensi Buku

\section{Populasi}

Populasi dalam penelitian ini adalah mahasiswa angkatan 2003 yang terdaftar dan aktif di Fakultas Pendidikan IImu Pengetahun Sosial Universitas
Pendidikan Indonesia (FPIPS-UPI) yang mengkonsumsi Teh Kotak Ultrajaya.

Berdasarkan populasi tersebut, selanjutnya diambil sampel dengan menggunakan rumus Slovin sebagai berikut: 
Diketahui:

$$
\begin{aligned}
\mathrm{N} & =205 \text { responden } \\
e & =0,1 \\
n & =\frac{N}{1+N e^{2}} \\
n & =\frac{205}{1+205(0,1)^{2}} \\
n & =\frac{205}{3} \\
n & =68,3 \text { Sampel }
\end{aligned}
$$

Agar memperoleh keakuratan yang lebih baik, maka jumlah sampel ditambah hingga menjadi 70 sampel. Sampel tersebut kemudian didistribusikan secara proporsional, dengan perhitungan yang disajikan pada Tabel berikut ini.

Tabel 8

Daftar Penyebaran Proporsi Sampel

\begin{tabular}{|c|c|c|c|}
\hline No & $\begin{array}{c}\text { JURUSAN/ } \\
\text { PROGRAM STUDI }\end{array}$ & $\mathrm{N}$ & $\mathrm{n}$ \\
\hline 1. & PMPKN & 20 & $\frac{20}{205} \times 70=7$ \\
\hline 2. & SEJARAH & 15 & $\frac{15}{205} \times 70=5$ \\
\hline 3. & GEOGRAFI & 13 & $\frac{13}{205} \times 70=4$ \\
\hline 4. & $\begin{array}{c}\text { PENDIDIKAN } \\
\text { AKUNTANSI }\end{array}$ & 7 & $\frac{7}{205} \times 70=2$ \\
\hline 5. & $\begin{array}{c}\text { TATA NIAGA } \\
\text { IMANAJEMEN BISNIS }\end{array}$ & 31 & $\frac{31}{205} \times 70=11$ \\
\hline 6. & $\begin{array}{c}\text { ADMINISTRASI } \\
\text { PERKANTORAN }\end{array}$ & 25 & $\frac{25}{205} \times 70=9$ \\
\hline 7. & $\begin{array}{c}\text { EKONOMI KOPERASI } \\
8 .\end{array}$ & 16 & $\frac{16}{205} \times 70=5$ \\
\hline 9. & MANAJEMEN & 38 & $\frac{38}{205} \times 70=13$ \\
\hline & AKUNTANSI & 40 & $\frac{40}{205} x 70=14$ \\
\hline
\end{tabular}

Sumber : Hasil Pengolahan Data 2007

\section{HASIL PENELITIAN DAN PEMBAHASAN}

\section{Pengaruh Variasi Produk Terhadap Keputusan Pembelian}

Hasil analisis statistik ternyata dari ketiga dimensi variasi produk yang diuji, yang memberikan pengaruh paling besar atau dominan terhadap keputusan pembelian konsumen adalah harga $\left(X_{1.2}\right)$ sebesar 0,4375 atau $43,75 \%$, ukuran $\left(X_{1.1}\right)$ memberikan pengaruh sebesar 0,1135 atau $11,35 \%$, sedangkan rasa $\left(X_{1.3}\right)$ memberikan pengaruh sebesar 0,0621 atau $6,21 \%$. Secara keseluruhan mempengaruhi keputusan pembelian konsumen sebesar $61,31 \%$ dan faktor lain di luar variasi produk yang mempengaruhi keputusan pembelian konsumen sebesar $38,69 \%$. Hal ini dapat diartikan bahwa masih ada faktor lain diluar variasi produk yang juga mempengaruhi keputusan pembelian konsumen, namun tidak dijelaskan dalam penelitian ini.

Variasi produk yang dilakukan oleh Teh Kotak Ultrajaya diantaranya dengan menambah varian rasa yang baru dan berbeda yaitu rasa blackcurrant orange dan apple dengan tujuan menarik konsumen agar tetap setia terhadap Teh Kotak Ultrajaya sebagai minuman teh siap dalam kemasan yang pertama di Indonesia yang pada akhirnya diharapkan dapat meningkatkan keputusan pembelian.

Hal tersebut sejalan dengan pendapat yang dikemukakan oleh Kotler (2000 :183), bahwa Dalam keputusan pembelian konsumen ada beberapa hal yang mempengaruhinya diantaranya faktor yang ditimbulkan dari rangsangan pemasaran dan faktor yang ditimbulkan dari luar rangsangan pemasaran. Rangsangan pemasaran terdiri dari $4 \mathrm{P}$, yaitu : product, price, place, promotion. Variasi produk berada pada rangsangan pemasaran yang bersumber dari produk.

Hal itu diperkuat oleh pendapat yang dikemukakan oleh Menurut Kotler dan Amstrong (2006:234), bahwa unsur produk yang dimiliki oleh suatu produk akan mempengaruhi keputusan pembelian konsumen terhadap suatu produk. Unsur produk tersebut adalah:

1. Keanekaragaman (product variety)

2. Kualitas produk (Quality)

3. Rancangan produk (Design)

4. Ciri-ciri produk (Features)

5. Merek produk (Brand name)

6. Kemasan produk (packaging)

7. Tingkat pelayanan (Service)

8. Garansi (Waranties)

9. ukuran produk (Size)

10. Pengembalian (Return)

\section{Pengaruh Kemasan Terhadap Keputusan Pembelian}

Hasil analisis statistik ternyata dari keenam dimensi kemasan yang diuji, yang memberikan pengaruh paling besar atau dominan terhadap keputusan pembelian konsumen adalah label $\left(X_{2.5}\right)$ 


\section{StrategiC}

sebesar 13,52\%, bentuk $\left(X_{2.1}\right)$ memberikan pengaruh sebesar $9,25 \%$, bahan $\left(X_{2.2}\right)$ memberikan pengaruh sebesar $8,83 \%$, warna $\left(X_{2.3}\right)$ memberikan pengaruh sebesar $8,39 \%$, gambar $\left(X_{2.4}\right)$ memberikan pengaruh sebesar $13,41 \%$. Secara keseluruhan mempengaruhi keputusan pembelian konsumen sebesar $53,40 \%$ dan faktor lain di luar kemasan yang mempengaruhi keputusan pembelian konsumen sebesar $46,59 \%$. Hal ini dapat diartikan bahwa masih ada faktor lain diluar kemasan yang juga mempengaruhi keputusan pembelian konsumen, namun tidak dijelaskan dalam penelitian ini.

Strategi kemasan yang dilakukan oleh Teh Kotak Ultrajaya yaitu dengan menambah isi/volume sebesar $50 \%$ ekstra untuk jenis jasmine tea dan $25 \%$ ekstra untuk jenis varian rasa. Hal ini diharapkan dapat memberikan kepuasan terhadap konsumen, yang pada akhirnya akan meningkatkan keputusan pembelian.

Konsumen memandang merek sebagai bagian penting dari produk, dan pembelian produk dapat menambah nilai guna suatu barang. (Kotler dan Amstrong, 2006:229). Ini menunjukkan bahwa merek merupakan sesuatu yang bisa membantu konsumen dalam melakukan pembelian dan untuk mengidentifikasi produk yang menguntungkan mereka. Kesimpulan dari pernyataan di atas bahwa merek merupakan salah satu dimensi dari kemasan, jadi dalam hal ini kemasan dapat mempengaruhi keputusan konsumen dalam melakukan pembelian.

Hal tersebut sejalan dengan pernyataan yang diungkapkan oleh Buchari Alma (2005:160) bahwa Konsumen selalu memiliki pertimbangan tertentu dalam membeli barang, dan daya tarik pertamanya terfokus pada bentuk, keindahan/ performance dari pembungkusnyal kemasan (package). Kemasan dapat berpengaruh terhadap konsumen, yang bersifat impulsif, emosional yang tidak direncanakan lebih dulu. Ini menimbulkan daya tarik produk. Apalagi bila konsumen sulit melakukan penilaian terhadap kualitas isi produk yang dikemas di dalamnya, kemasan merupakan reference point, titik pemula yang menarik yang dipandang oleh konsumen. Pada saat pertama kali pemunculan produk, atau pada saat introduksi, pada saat repositioning produk, peranan kemasan sangat penting, sebab ini merupakan perkenalan pertama bagi konsumennya. Perbedaan kemasan suatu produk dengan produk lainnya bisa disebabkan oleh volume isi yang terkandung di dalamnya, inovasi kemasan dalam berbagai hal, desain, praktis untuk dibawa, mudah dipegang, kuat, tahan lama, mudah dibuka, harmonis, kreatif, estetis, higienis, jelas terbaca dan menarik. Kemasan merupakan bagian dari formal produk, yang meliputi packaging, features, brand name, styling dan quality dengan kata lain, sebuah produk diasosiasikan dengan bentukpembungkusnya, fitur atau kelengkapan lain, merek, model, kualitas bahan, dsb. Sedangkan pada bagian kemasan terdapat beberapa ciri size, shape, material, color, graphies, brand name dan labelling. Ciri-ciri tersebut akan sangat berpengaruh pada konsumen, sebab konsumen akan mencari kesesuaian antara bentuk, materi pembungkus, warna, desain pembungkus, dsb, dengan seleranya. Konsumen akan memperoleh manfaat fungsional dan manfaat emosional dari kemasan tersebut.

Sedangkan Marwini dalam jurnal yang berjudul Kekuatan dan Daya Tarik Kemasan Industri Pangan (2003), mengemukakan bahwa Kemasan yang baik dirancang dengan mempertimbangkan kebutuhan dan keinginan baik konsumen ataupun pedagangnya. Desain kemasan yang baik akan mampu berfungsi optimal dalam mengkomunikasikan tentang produk tersebut kepada konsumennya dengan jelas. Meskipun akhirnya akan sampai juga kepada semua jenis konsumen yang ada di pasar, namun penting juga dipertimbangkan tentang tipe konsumen yang mana yang ingin kita pilih, dan bagaimana cara mereka akan menggunakan atau memanfaatkan produk yang kita kenalkan. Keinginan dan kebutuhan konsumen adalah ilham dan katalis yang kuat bagi inovasi kemasan. Pada saat ini ada beberapa keinginan dan kebutuhan konsumen yang memacu perkembangan desain dan model kemasan, diantaranya adalah gaya hidup masyarakat yang selalu bergerak cepat, meningkatnya patron keluarga kecil, tuntutan akan makanan sehat serta porsi dan diet yang terkontrol dll.

\section{Pengaruh Variasi Produk dan Kemasan Terhadap Keputusan Pembelian}

Berdasarkan hasil pengujian hipotesis ketiga ini menghasilkan nilai signifikansi bagi $X_{1}$ dan $X_{2}$ sebesar 0,000 lebih kecil jika dibandingkan dengan 0,05 dengan demikian diambil kesimpulan bahwa Ho ditolak. Pengujian juga dapat dilakukan dengan membandingkan $t_{\text {hitung }}$ dengan tabel untuk $\alpha=0,05$, 
hasil perhitungan menunjukkan bahwa thitung bagi $X_{1}$ dan $\mathrm{X}_{2}$ sebesar 6,017 dan 5,367 lebih besar dari tabel yaitu 1,667 , artinya Ho ditolak. Hal tersebut menunjukkan bahwa variasi produk dan kemasan berpengaruh terhadap keputusan pembelian.

Hal tersebut sejalan dengan pendapat yang dikemukakan oleh Kotler dan Amstrong (2006: 234), bahwa Unsur produk yang dimiliki oleh suatu produk akan mempengaruhi keputusan pembelian konsumen terhadap suatu produk. Unsur produk tersebut adalah:

1. Keanekaragaman (product variety)

2. Kualitas produk (Quality)

3. Rancangan produk (Design)

4. Ciri-ciri produk (Features)

5. Merek produk (Brand name)

6. Kemasan produk (packaging)

7. Tingkat pelayanan (Service)

8. Garansi (Waranties)

9. Ukuran produk (Size)

10. Pengembalian (Return)

Dari pendapat diatas dapat diketahui bahwa variasi produk dan kemasan merupakan bagian dari unsur sebuah produk yang dapat mempengaruhi keputusan pemebelian konsumen.

\section{SIMPULAN DAN SARAN}

\section{Simpulan}

Berdasarkan penjelasan teori, pengolahan data serta analisis data dalam penelitian ini yang telah diuraikan sebelumnya, maka penulis dapat mengambil kesimpulan sebagai berikut.

1. Berdasarkan hasil tanggapan responden mengenai variasi produk minuman teh dalam kemasan Teh Kotak Ultrajaya, yang terdiri dari ukuran, harga, dan rasa dapat diketahui bahwa item pertanyaan keterjangkauan harga memperoleh skor tertinggi, dalam hal ini harga merupakan bagian dari variasi produk yang paling penting, karena harga biasanya akan mempengaruhi keputusan pembelian konsumen. Konsumen dalam membeli sesuatu berdasarkan kebutuhan tertentu dan mengharapkan produk tersebut sesuai dengan harapannya. Mereka mengevaluasi beberapa produk dalam penawaran dan mengambil keputusan yang terbaik. Sedangkan rasa blackcurrant memperoleh skor terkecil.

2. Berdasarkan hasil tanggapan responden mengenai kemasan Teh Kotak Ultrajaya diketahui bahwa item pertanyaan yang memperoleh skor tertinggi adalah bahan kemasan yang tahan lama, dengan adanya pembungkus/kemasan barang-barang tetap bersih dan praktis untuk dibawa ke rumah, tahan lama dan mudah disimpan. Hal ini menjadi pertimbangan konsumen dalam membeli Teh Kotak Ultrajaya. Sedangkan item pertanyaan ketertarikan terhadap warna memperoleh skor terkecil.

3. Hasil tanggapan responden mengenai keputusan pembelian yang terdiri dari jenis produk, bentuk produk, pilihan merek, pilihan saluran penjual dan waktu pembelian dapat diketahui bahwa item pertanyaan yang memperoleh skor tertinggi adalah kemudahan mendapatkan produk melalui saluran penjual. Hal ini dikarenakan produk Teh Kotak Ultrajaya tersedia di berbagai saluran penjualan, seperti supermarket, minimarket, toko/warung, dan lain-lain, sehingga membuat konsumen mudah untuk membelinya. Dengan kata lain bahwa yang menjadi pertimbangan pada saat melakukan keputusan pembelian Teh Kotak Ultrajaya adalah kemudahan memperoleh produk melalui penyalur atau distributor. Sedangkan item pertanyaan ketertarikan pada bentuk produk dan jenis produk varian rasa memperoleh skor terkecil.

4. Variasi produk yang dilakukan oleh Teh Kotak Ultrajaya, yang terdiri dari ukuran, harga, dan rasa berpengaruh positif dan signifikan terhadap keputusan pembelian. Dari hasil penelitian didapat bahwa $t_{\text {hitung }}>t_{\text {tabel }}$ maka $\mathrm{Ho}$ ditolak. Dari seluruh dimensi variasi produk dimensi harga yang mempunyai pengaruh terbesar terhadap keputusan pembelian yaitu sebesar $43,75 \%$, sedangkan rasa merupakan dimensi yang memiliki pengaruh terkecil terhadap keputusan pembelian yaitu sebesar $6,21 \%$, pengaruh variasi produk untuk dimensi ukuran terhadap keputusan pembelian adalah sebesar $11,35 \%$. Sehingga secara keseluruhan total pengaruh variasi produk terhadap keputusan pembelian adalah sebesar $61,31 \%$ atau bisa dikategorikan ke dalam korelasi kuat, sedangkan sebesar $38,69 \%$ dipengaruhi oleh faktor lain yang tidak termasuk ke dalam penelitian ini.

5. Sedangkan untuk kemasan Teh Kotak Ultrajaya yang terdiri dari bentuk, bahan, warna, gambar, dan label berpengaruh positif dan signifikan 
terhadap keputusan pembelian. Dari seluruh dimensi kemasan, dimensi label yang mempunyai pengaruh terbesar yaitu sebesar $13,52 \%$, sedangkan untuk dimensi yang memberikan pengaruh terkecil adalah dimensi warna yaitu sebesar $8,39 \%$, untuk dimensi bentuk mempunyai pengaruh sebesar $9,25 \%$ terhadap keputusan pembelian, untuk dimensi bahan mempunyai pengaruh sebesar 8,83\% terhadap keputusan pembelian, untuk dimensi gambar berpengaruh terhadap keputusan pembelian sebesar $13,41 \%$. Sehingga secara keseluruhan total pengaruh kemasan terhadap keputusan pembelian adalah sebesar $53,40 \%$ atau bisa dikategorikan ke dalam korelasi sedang, sedangkan sebesar 46,59\% dipengaruhi oleh faktor lain yang tidak termasuk ke dalam penelitian ini.

6. Variabel independen yang terdiri dari variasi produk $\left(X_{1}\right)$ dan kemasan $\left(X_{2}\right)$ berpengaruh positif dan signifikan terhadap keputusan pembelian $(\mathrm{Y})$, dengan demikian Ho ditolak dan Ha diterima. Berdasarkan hasil perhitungan diketahui bahwa variasi produk dan kemasan secara bersama-sama memberikan pengaruh sebesar $67,93 \%$ terhadap keputusan pembelian atau bisa dikategorikan ke dalam korelasi kuat, sedangkan sebesar $32,07 \%$ dipengaruhi oleh faktor lain yang tidak termasuk ke dalam penelitian.

\section{Saran}

Berdasarkan hasil penelitian, hal-hal yang dapat peneliti sarankan yaitu:

1. Variasi produk merupakan salah satu strategi yang dilaksanakan oleh Teh Kotak Ultrajaya untuk dapat meningkatkan keputusan pembelian. Berdasarkan hasil tanggapan responden terhadap variasi produk yang dilaksanakan oleh Teh Kotak Ultrajaya, rasa blackcurrant merupakan item pertanyaan yang mendapatkan skor terkecil jika dibandingkan dengan dimensi harga dan ukuran. Oleh karena itu sebaiknya Teh Kotak Ultrajaya harus lebih memperhatikan keinginan dan kebutuhan konsumen terhadap rasa dari produk Teh Kotak Ultrajaya, apakah variasi rasa yang dilaksanakan oleh Teh Kotak Ultrajaya sudah sesuai dengan kebutuhan konsumen sehingga konsumen tidak akan merasa kecewa. Jika konsumen sudah merasa kecewa terhadap produk tersebut maka mereka tidak akan percaya lagi pada produk tersebut dan kemungkinan mereka akan berpindah ke produk lain yang lebih bisa memuaskan mereka. Selain itu Teh Kotak Ultrajaya harus lebih peka terhadap selera konsumen yang berbeda terhadap rasa dari suatu produk minuman teh dalam kemasan, karena tidak semua orang menyukai teh dengan rasa buah-buahan. Perusahaan sebaiknya memberikan sampel Teh Kotak untuk jenis varian rasa supaya konsumen tertarik untuk membelinya.

2. Berdasarkan hasil tanggapan responden terhadap kemasan yang dilaksanakan oleh Teh Kotak Ultrajaya, ketertarikan terhadap warna merupakan item pertanyaan yang mendapatkan skor terkecil. Oleh karena itu Teh Kotak Ultrajaya harus mempertimbangkan komposisi warna dalam kemasan karena warna kemasan yang unik dan menarik akan memberikan kesan yang menarik bagi konsumen terhadap suatu produk, sehingga warna kemasan yang selaras akan terlihat indah dipandang. Warna adalah salah satu dari dua unsur yang menghasilkan daya tarik visual dan pada kenyataannya warna lebih berdaya tarik terhadap emosi daripada akal. Orang lebih menyenangi warna merupakan bagian dari keseriusan manusia.

3. Proses pengambilan keputusan yang rumit sering melibatkan beberapa keputusan. Suatu keputusan (decision) melibatkan pilihan di antara dua atau lebih alternatif tindakan (perilaku). Keputusan selalu mensyaratkan pilihan di antara beberapa perilaku yang berbeda. Berdasarkan hasil tanggapan responden terhadap keputusan pembelian Teh Kotak Ultrajaya, ketertarikan pada bentuk kemasan dan jenis produk varian rasa mendapatkan skor terkecil. Oleh karena itu Teh Kotak Ultrajaya harus dapat mengembangkan dan memperbaiki bentuk kemasan dengan lebih menarik lagi, misalnya membuat kemasan dengan bentuk segitiga, segilima, oval, dan lain sebagainya. Selain itu juga Teh Kotak Ultrajaya harus melakukan promosi yang lebih gencar terhadap jenis produk varian rasa kepada konsumen, supaya konsumen lebih mengenal Teh Kotak Ultrajaya sebagai produk minuman teh dalam kemasan 
yang menyediakan teh dengan rasa beraroma buah.

4. Variasi produk yang dilakukan oleh Teh Kotak Ultrajaya, yang terdiri dari ukuran, harga, dan rasa berpengaruh positif dan signifikan terhadap keputusan pembelian. Dari seluruh dimensi variasi produk dimensi rasa merupakan dimensi yang memiliki pengaruh terkecil terhadap keputusan pembelian yaitu sebesar $6,21 \%$, hal ini harus diperbaiki oleh Teh Kotak Ultrajaya dengan melakukan beberapa strategi yang belum dilaksanakan oleh perusahaan, diantaranya dengan mengadakan promosi Teh Kotak Ultrajaya jenis varian rasa, sehingga konsumen akan lebih mengenal Teh Kotak Ultrajaya. Misalnya memberikan sampel gratis Teh Kotak Ultrajaya untuk jenis varian rasa, sehingga konsumen lebih mengenal produk tersebut dan terbiasa dengan rasa baru yang ditawarkan oleh Teh Kotak Ultrajaya.

5. Kemasan Teh Kotak Ultrajaya yang terdiri dari bentuk, bahan, warna, gambar, dan label berpengaruh positif dan signifikan terhadap keputusan pembelian. Dari seluruh dimensi kemasan, dimensi yang memberikan pengaruh terkecil adalah dimensi warna yaitu sebesar $8,39 \%$. Oleh karena itu Teh Kotak Ultrajaya harus membuat komposisi warna yang kreatif dan unik, sehingga konsumen akan lebih tertarik untuk membeli produk tersebut. Kemasan yang memiliki warna-warna yang indah dan menarik akan mempengaruhi konsumen dalam pembelian suatu produk.

6. Variabel independen yang terdiri dari variasi produk $\left(X_{1}\right)$ dan kemasan $\left(X_{2}\right)$ berpengaruh positif dan signifikan terhadap keputusan pembelian $(\mathrm{Y})$. Berdasarkan hasil perhitungan diketahui bahwa variasi produk dan kemasan secara bersama-sama memberikan pengaruh sebesar 67,93\% terhadap keputusan pembelian. Oleh karena itu untuk dapat meningkatkan keputusan pembelian Teh Kotak Ultrajaya harus melakukan beberapa strategi yang belum dilaksanakan oleh perusahaan, diantaranya dengan mengadakan promosi dalam bentuk event-event, atau hadiah langsung jika melakukan pembelian Teh Kotak Ultrajaya, mengadakan kegiatan bazaar yang mempromosikan Teh Kotak Ultrajaya, memasang iklan di media televisi, radio, dan lain-lain agar dapat menarik minat dan perhatian konsumen terhadap produk Teh Kotak Ultrajaya, meningkatkan kualitas produk sehingga mampu bersaing dengan produkproduk yang lain, tetap mempertahankan rasa yang khas yang dimiliki Teh Kotak Ultrajaya agar konsumen tetap ingat pada produk tersebut, perusahaan harus lebih cermat dan teliti dalam menganalisis perilaku pembelian konsumen yang bervariasi dan selalu berubah, agar dapat menghasilkan produk yang bisa memberikan kepuasan kepada konsumen, setelah mereka merasakan kepuasan akan produk yang mereka beli, maka diharapkan mampu meningkatkan keputusan pembelian.

\section{DAFTAR PUSTAKA}

Buchari Alma. 2005. Manajemen Pemasaran dan Pemasaran Jasa. Bandung: CV. Alfabeta.

E. P. Danger. 1992. Memilih Warna Kemasan. Cetakan 1 Seri Umum No. 9. Jakarta: Pustaka Bremas Pressido.

Fandy Tjiptono. 1997. Strategi Pemasaran. Edisi II. Yogyakarta: Andi.

Fandy Tjiptono. 2002. Strategi Pemasaran. Yogyakarta, Penerbit : Andi

Fandy Tjiptono. 2005. Pemasaran Jasa. Malang: Bayumedia Publishing

Harun Al Rasyid. 1994. Teknik Penarikan Sampel dan Pengukuran Skala. Bandung: Pasca Sarjana UNPAD.

Husein Umar. 2001. Metode Riset Perilaku Organisasi. Jakarta: PT. Gramedia Pustaka Utama.

Kotler, Phillip \& Kevin L. Keller. 2006. Marketing Management, 12 $^{\text {th }}$ Edition. New Jersey: Pearson International Edition.

Nirwana SK Sitepu. 1994. Analisis Jalur (Path Analysis). Jurusan Statistika, FPMIPA Universitas Padjadjaran Bandung.

Philip Kotler dan Gary Amstrong. 2006. Principles of Marketing Eleventh Edition. New Jersey: Prentice hall International Inc.

Philip Kotler. 2005. Manajemen Pemasaran. Jakarta: PT INDEKS Kelompok Gramedia.

Schiffman, Leon.G. dan Kanuk, Leslie. 2003. Consumer Behavior. Jakarta: Prentice Hall Internasionallnc

Sugiyono. 2007. Metode Penelitian Bisnis. Bandung CV. Alfabeta. 
Suharsimi Arikunto. 2002. Prosedur Penelitian: Suatu Pendekatan Praktek. Jakarta : Rineka Cipta.

Suharsimi Arikunto. 2006. Prosedur Penelitian. Jakarta: Rineka Cipta.

Suharyadi Purwanto. 2004. Statistika untuk Ekonomi dan Keuangan Modern. Jakarta salemba Empat.

Uber Silalahi. 2006. Metode Penelitian Sosial. Bandung: Universitas Parahyangan Press.

Ujang Sumarwan. 2003. Perilaku Konsumen (Teori dan Penerapannya dalam Pemasaran). Jakarta: Ghalia Indonesia

Uma Sekaran. 2006. Metodologi Penelitian untuk Bisnis. Jakarta: Salemba 4.

Umar, Husein. 2003. Metode Riset Bisnis. Jakarta: Penerbit PT. Gramedia Pustaka Utama.

Yazid. 2005. Pemasaran Jasa: Konsep dan Implementasi. Yogyakarta: Ekonisia Kampus FE UII.

Zeithaml, Valerie A. \& Mary Jo Bitner. 2006. Service Marketing Integrating Customer Focus Across The Firm. New Jersey: Prentice Hall International, Inc.

Zikmund, William G. 2003. Exploring Marketing Research 8th Edition. USA, Ohio: South Western, A Division of Thomson Learning. 